INOBIS: Jurnal Inovasi Bisnis dan Manajemen Indonesia

Volume 1, Nomor 4, September 2018

Anas Hidayat ; Jaya Addin Linando; Sri Rejeki Ekasasi

\title{
The Impact of University's Programs Toward Alumni Perceived Development (A Case Study in International Program, Faculty of Economics, Islamic University of Indonesia)
}

\author{
Anas Hidayat, Drs., M.B.A., Ph.D. ${ }^{1}$ (anas.hidayat1988@gmail.com) \\ Jaya Addin Linando, S.E., M.B.A. ${ }^{1}$ (addinlinando@gmail.com) \\ Sri Rejeki Ekasasi, Dra., M.B.A. ${ }^{2}$ (sekasasi@gmail.com) \\ ${ }^{1}$ Prodi Manajemen, Fakultas Ekonomi, Universitas Islam Indonesia \\ ${ }^{2}$ Sekolah Tinggi Ilmu Manajemen (STIM) - YKPN, Yogyakarta
}

\begin{abstract}
Education plays an important role as the value-shaper students. International Program Faculty of Economics, Universitas Islam Indonesia or IPFE UII is one of the universities that have role in education. IPFE UII is intended to be the value-shaper for its students. One of the way that is done by IPFE UII to achieve that goal is by providing several character building programs. IPFE UII compresses the values and tried it into five points, they are: professional behaviour, creative thinking, literacy skill, global understanding and communication skill. This research was done to evaluate whether the programs of IPFE UII have an impact on the perceived development of its students or not. The results of this research shows that based on simple regression analysis, all five variables are significantly influence perceived development as the dependent variable. While the result shown in multiple regression analysis are: 1) professional behaviour has positive significant influence to alumni perceived development; 2) creative thinking has negative influence to alumni perceived development; 3) literacy skill has positive but not significant influence to alumni perceived development; 4) global understanding has positive but not significant influence to alumni perceived development; 5) communication skill has positive influence to alumni perceived development.
\end{abstract}

Keywords: Professional Behaviour, Creative Thinking, Literacy Skill, Global Understanding, and Communication Skill.

\section{Introduction}

In this globalization era, education is an important tool as one of the solutions to face any challenges in the dynamic business world. Nowaday, many aspects of people's life are changing and shifting, including business aspect. In business world, now we see how human is competing to be successful in his/her career, not only with another human, but also with the machines, as the consequences of technology advancement. The point is, that human should not only be smarter, faster and stronger in order to survive in his/her career, but also one should show his/her best in fulfilling his/her jobdesks. This is where education takes part, to prepare human to be able to maximize his/her potentials.

International Program of Faculty of Economics, Islamic University of Indonesia (in Bahasa called as 'Universitas Islam Indonesia') is one of the universities that shares the same concern toward the issue of global era competition. Thus, International Program of Faculty of Economics, Islamic University of Indonesia (later on in this paper, it will be called as IPFE UII) is preparing a set of programs, known as 'Character Building Program'. The main goal of the programs is stated on IPFE UII's vision and mission statement, to harmonize between 
INOBIS: Jurnal Inovasi Bisnis dan Manajemen Indonesia

Volume 1, Nomor 4, September 2018

Anas Hidayat ; Jaya Addin Linando; Sri Rejeki Ekasasi

hearts-head-hands. Meaning that IPFE UII is not only trying to create an intellectual person (head), but also a person who can contribute positively to society (hand), more than that, IPFE UII is also expecting its alumni to be a person with a strong and righteous characters (heart).

To achieve its goal, IPFE UII Character Building Program is designed on the pathway inline with the goal. The programs are: LKID, LKIM \& LKIL (Latihan Kepemimpinan Islam Dasar-Menengah-Lanjut. In English: Basic-Intermediate-Advanced Islamic Leadership Training) which focuses on shaping student's character (heart). OMT 1,2,3 (Outbound Management Training, in series, 1 to 3 ) which focuses on shaping student's character (heart) and the spirit of compassion and serving (hand), and for sure the daily teaching activity in class is also be the part of Character Building Program which focuses in shaping student's mind to be widely open (head).

In the context to achieve heart-head-hand harmonization for the alumni, those programs are designed with values and skills inside them. There are at least five skills within the programs that IPFE UII trying to deliver to its students. The skills are: Professional Behaviour, Good Literacy, Creative Thinking, Global Understanding and Good Communication. IPFE UII believes that those are the main skills needed to be successful in business world today, whether the students would like to be an employee, an entrepreneur, a lecturer, etc, the skills will very much helpful for them in the future.

As the conclusion, this research is done to evaluate tool for IPFE UII, whether or not its programs already achieve the objectives and already on the right track on achieveng the objectives. The subject of the research is the 'consumer' of IPFE UII, the alumni of IPFE UII, as they have graduated from IPFE UII and face the real business world.

In this research, the dependent variable will be 'Perceived Development' of IPFE UII alumnae. The elements of perceived development are: Personal Development, Professional Development and Academic Development.

\section{Literature Review}

\subsection{Professional Behaviour and Perceived Development}

Professional behaviour is one of the most important trait for every university to be delivered to its graduates. Because at the end, the development of university's graduates is representing the name of the university, thus every university will make sure that their graduates have the good quality as a professional. It is in line with what Clark, Mathur \& Schoenfeld (2009) suggest, that professional development serves a very specific role within capacity building (character building, in IPFE's term). Which means that the process to build the professional value using capacity/character building is a correct method.

Capacity building for shaping professional behaviour consists of three essential components (Clark, Mathur \& Schoenfeld, 2009): first, the professional development should be based on the principles of adult learning. This is already being applied in IPFE UII, in IPFE UII's programs, the method being used is andragogy method. Andragogy is the theory of adult learning that sets out the scientific fundamentals of the activities of learners and teachers (Kroth \& Taylor, 2009). IPFE UII provides outbound management training, where the facilitators are required to be passive, and the main 'actors' on the program is the participant, with this method, it is hoped that the participants can learn as much as possible and get more lessons to be transformed into the professional trait later on.

Second component is that professional development should be systemic. This is also what IPFE UII provide to its students, the Character Building Programs are not programs that spontaneously occurred. IPFE UII design the programs in an arranged curriculum, and one 
INOBIS: Jurnal Inovasi Bisnis dan Manajemen Indonesia

Volume 1, Nomor 4, September 2018

Anas Hidayat ; Jaya Addin Linando; Sri Rejeki Ekasasi

program to another is in line and contain sequential values inside them. For example, OMT I (Outbound Management Training I) is containing the value of knowing ourselves as a person, then continued by OMT II with the value of serving others, and finally closed by OMT III with the value of being prepared to face the real world as a professional.

The third, it should include an ongoing evaluation. Which also done by IPFE UII, every year and after every program, the evaluation is held, and the betterment of programs' concepts are made to be applied for the next program period. This lead to the first hypothesis formulation where H1: Professional behaviour influences the perceived development of IPFE UII alumni.

\subsection{Creative Thinking and Perceived Development}

In this dynamic world, IPFE UII as an univeristy believe that creativitiy or creative thinking is a trait that becomes more important now than ever. Nowaday, there are abundant number of bachelor degree holders in the jobseeking competition, thus any bachelor should have his/her added value in order to be the better candidate for the job or to show the better performance among others in the work environment. The trait needed to face current competition should be 'creativity', as the dynamic world requires dynamic problem solving too, and dynamic problem solving requires a lot of creativity.

Jacques (2003) argue that it is a creativity that will enable individuals to maneuver throughout one's life in ways that are most productive, efficient, and rewarding. These elements (productive, efficient and rewarding) are the elements needed to face the current dynamic business world. It is in line with what Ali et al (2013) suggest, that in today business world, creativity is one of the value need to be obtained by anyone live in today era.

In many literatures, it is agreed that creativity is linked to productivity and quality enhancement (Jacques, 2003). This is what the research trying to find out, whether the theory also relevant in IPFE UII case or not, that the university's programs related to creativity trait led to good perceived performace in IPFE UII alumni's mind. In hypothesis, it is believed that H2: Creativity influences the perceived development of IPFE UII alumni.

\subsection{Literacy and Perceived Development}

Literacy definition in this research is a skill to write and understand the written documents, beyond that, literacy skill can also be defined as the ability to analyze the written documents such as paper, article, etc. Probably this is one of the most important skills that is not really well thought by the universities when they are preparing their students to be able to lead the business world in the future. What writer mean by that, is, that most universities does not really have a specific program to enhance this skill for their students. Meanwhile, it is believed that advanced literacy or also called as analytical skills is a prerequisite to adult success in the twenty-first century (Murnane et al, 2012).

IPFE UII is trying to deliver this value to its student through the programs IPFE UII made. In LKID-M-L (Latihan Kepemimpinan Islam Dasar-Menengah-Lanjut/Islamic Leadership Training Basic-Intermediate-Advance), literacy skill is one of the most well noted skill to be mastered by the participants. It is in line with what Heneman (1999) suggests, that the successsful programs must provide their graduates with analytical or literacy skills. For this part, the hypothesis would be H3: Literacy influences the perceived development of IPFE UII alumni. 
INOBIS: Jurnal Inovasi Bisnis dan Manajemen Indonesia

Volume 1, Nomor 4, September 2018

Anas Hidayat ; Jaya Addin Linando; Sri Rejeki Ekasasi

\subsection{Global Understanding and Perceived Development}

The term 'Global' is being an interesting topic to be discussed currently. It is because now the world are being more borderless and the exchanges of culture, commodities, and everything between countries are becoming much easier to be done. Some agreements intercountries are being made, says, AFTA (Asean Free Trade Area), NAFTA (North American Free Trade Area), AEC (Asean Economic Community), etc. This phenomenon create a lot of new terms in the business world. 'Global leader' is being a new paradigm that being the concern of IPFE UII.

Theoretically, some scholars argue that there is no true distinction between a domestic and a global leader, it is only a matter of functioning at higher levels that creates a distinction among them. (Forsyth \& Maranga, 2015). In their research, Forsyth and Maranga (2015) summarize the skills needed to be success competing in the global environment, the skills are: cognitive skills; emotional resilience; personal drive; cross-cultural skills.

We can see how the skills needed in the global world, according to them, are not really different with the skills needed to lead successfully in the local environment, it just added another specific skill, that is 'cross-cultural' ability, which is also being an iconic skill of the globalized world. Meaning that, to teach global understanding to the students, all we need to do is to make them familiar and aware that there are a lot of cultural richness in this world. IPFE UII is trying to deliver the value by offering exchange program, the students are encouraged to go overseas through the program, and IPFE UII also accepting students from overseas to study in IPFE UII. By doing so, it is expected that the students are experiencing cultural exchanges and make them more aware and sensitive toward this issue, and hopefully will led to the better global understanding for the students.

IPFE UII also optimistic that the method it used to shape a good global understanding for its student is already on the right track. IPFE UII oblige every students to speak English in the class learning process in order to make the students being used to global environment.Tochon (2009) suggest that using English as the main language in university learning process will bring many benefits, the benefits are: language learning supports academic achievement; language learning provides cognitive benefits to students; language learning affects attitudes and beliefs about the language itself and other cultures.

Based on these theoritical backgrounds, it is believed that global understanding skill will be the added value of students and will be useful for them once they are graduated and face the real business world. The hypothesis of this section is H4: Global understanding influences the perceived development of IPFE UII alumni.

\subsection{Communication and Perceived Development}

Communication is an important must-have skill for anyone to be able to compete in this global era. Kleckner and Marshall (2015) found that employers have consistently expressed concerns about communication skill deficits among new hires entering the workforce. They also suggest that this is being one of the big task of the universities to deliver and shape this skill to their students.

Communication skills can be categorized into two big categories, it is writting communication and oral communication skills (Kleckner \& Marshall, 2015). Writting communication skill in this research is being included in 'literacy' skill. So the focus of this section is in oral communication skill. There are several variables inside oral communication skill according to Kleckner and Marshall (2015), they are: general oral skills; oral 
INOBIS: Jurnal Inovasi Bisnis dan Manajemen Indonesia

Volume 1, Nomor 4, September 2018

Anas Hidayat ; Jaya Addin Linando; Sri Rejeki Ekasasi

communication with colleagues; oral communication with clientsl; negotiation skills; presentation skills.

IPFE UII trying to deliver the skills through one of its Character Building Program. It is through Bridging Program, a special program made by IPFE UII for the new students. The goal is to bridge the students, in term of the changes period from high school cultures into university cultures. In the program, students are encouraged to speak as frequently as possible, the program is student-centered, and its success criteria is measured by students development, by comparing their performance and motivation before and after the program. It is believed that the communication skill is one of the important skill for the students to compete in the world after they are graduated from the university. The hypothesis is H5: Communication skill influences the perceived development of IPFE UII alumni.

\subsection{Hypotheses Formulation}

The previous section has discussed about the research and writings from prior studies about the associated topics in this research. This section will discuss about the formulation of hypothesis based on prior findings and theory. According to Babin et al. (2009), a hypothesis is a formal statement of unverified proposition which explaining some outcome and empirically testable. Hypothesis aims to give the best framework to solve the research problem formulation. To put it simple, hypothesis is the way to find the answers of research problem.

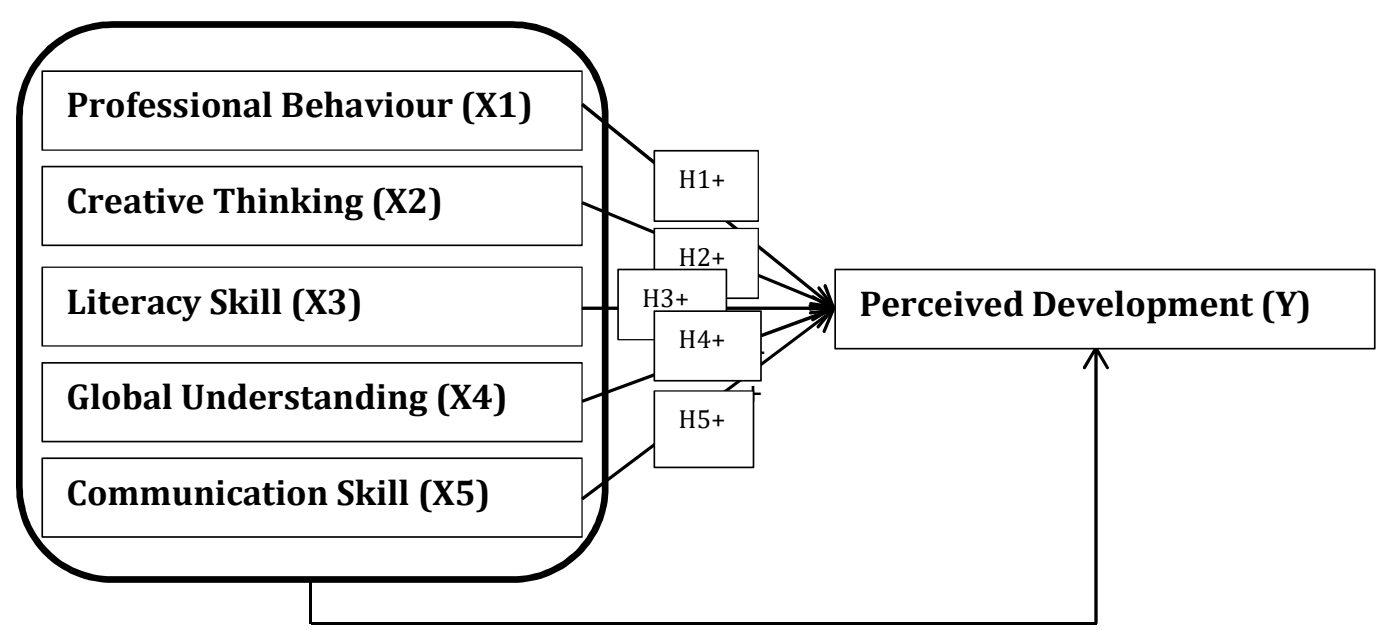

Figure 2.1. Conceptual Framework

\section{Research Methodology}

\subsection{Research Instrument}

This research utilizes a quantitative method and utilizes questionnaire as the data collection method, with IPFE UII alumni as the research object. The population of this research are all alumni of IPFE UII from all majors (there are 3 majors; Management, Accounting, Economics) with the range of the first batch of graduation, which is 1999 graduates until the batch of 2014 graduates. There are no specific limitation whose can join the survey, as long as the person is IPFE UII alumni, then they are justified to join the survey. 
INOBIS: Jurnal Inovasi Bisnis dan Manajemen Indonesia

Volume 1, Nomor 4, September 2018

Anas Hidayat ; Jaya Addin Linando; Sri Rejeki Ekasasi

This survey is using simple convenient sample technique. This technique is chosen because the spread of IPFE UII alumni is quite wide with the constraint of minimum channel to reach them and also because there is a big gap of the total students graduated per year thus it is difficult to make alumni ratio using graduation batch as the base of categorization. In the end of the survey, there are 92 alumni participated to evaluate IPFE UII's programs.

The kind of data that will be used in this survey is primary data which is gathered directly from target respondents through the questionnaires. The questionnaires consist of 3 question parts as follows: Part I, it contains some questions about personal information and respondents' identity. Part II, it contains some statements that will express respondents' assessment on learning process and character building during their study at IPFE UII and its reflection toward their perceived development. Part III, it contains some questions that will present advices, recommendations and suggestions from respondents for the quality improvements of academic and non-academic program at IPFE UII.

\subsection{Reliability and Validity}

Validity test is used to test whether the questions asked to the respondents are valid or not. The technique used to test the validity is by correlating the statistical value of each question with the total score of the questions. The tool being used is the Pearson Product Moment. The question will be considered valid when $r$ count is equal to or more than $r$ table $(r$ count value $=>r$ table value). The significance level being used in this research is $5 \%$.

Reliability test will determine the consistency level of respondents' responses to the questions being asked in the questionnaire. In this research, reliability test was done used Cronbach's Alpha test method. When the value of Cronbach's Alpha is greater than 0,6 ( $\square>$ $0,6)$, then the questions will be considered reliable, and vice versa, when the value is below or equal to 0,6 , then the questions will be considered not reliable. Both of reliability and validity test was done used SPSS 18.0 software.

\subsection{Data Analysis}

This research utilizes multiple regression equation. According to Babin et al. (2009), multiple regression analysis is an investigation of the effects of two or more independent variables on a single, interval-scaled dependent variable that investigated simultaneously. The significance of independent variables to dependent variable shows the probability value $(\beta)$ from the $t$ test of each independent variable at the significant level of $5 \%$. The researcher formulates Null Hypotheses (H0) and Alternative Hypotheses (Ha) which have to be tested to prove whether the hypotheses are rejected or accepted. The $r$ table for this research is 0,205 , with the critical value of Cronbach Alpha 0,6. Table 4.1. is showing the result of data analysis:

Table 3.1. Validity and Reliability Analysis

\begin{tabular}{|l|l|l|}
\hline Items & Correlation Coefficient Number & Cronbach Alpha \\
\hline PB1 & 0.811 & 0,844 \\
\hline PB2 & 0.835 & \\
\hline PB3 & 0.789 & \\
\hline PB4 & 0.867 & \\
\hline C1 & 0.854 & 0,893 \\
\hline C2 & 0.883 & \\
\hline C3 & 0.890 & \\
\hline
\end{tabular}


INOBIS: Jurnal Inovasi Bisnis dan Manajemen Indonesia

Volume 1, Nomor 4, September 2018

Anas Hidayat ; Jaya Addin Linando; Sri Rejeki Ekasasi

\begin{tabular}{|l|l|l|}
\hline C4 & 0.856 & \\
\hline L1 & 0.690 & 0,803 \\
\hline L2 & 0.774 & \\
\hline L3 & 0.869 & \\
\hline L4 & 0.839 & 0,870 \\
\hline GU1 & 0.858 & \\
\hline GU2 & 0.840 & \\
\hline GU3 & 0.850 & \\
\hline GU4 & 0.849 & 0,874 \\
\hline COM1 & 0.850 & \\
\hline COM2 & 0.834 & \\
\hline COM3 & 0.887 & \\
\hline COM4 & 0.836 & 0,855 \\
\hline PERSDEV & 0.875 & \\
\hline ACADEV & 0.872 & \\
\hline PROFDEV & 0.875 & \\
\hline
\end{tabular}

The test results obtained from the reliability coefficients for all variables used in this study is greater than the critical value of 0.6. Therefore, it can be concluded thet all of the questions in the questionnaire of this study can be stated as reliable. Table 4.5 shows the result of reliability test for all of the question instruments. The Cronbach Alpha Value $(\alpha)$ of the Professional Behaviour is 0.844 , the Creativity is 0.893 , the Literacy is 0.803 , and Global Understanding is 0.870 , the Communication is 0,874 and the Perceived Development is 0,855. This shows that all of variables have Cronbach Alpha Value that is greater than Critical Value (0.60). This means that the questionnaire had consistent results when measured in different time, models, or designs.

\section{Hypothesis Testing}

The first hypothesis of equation is to verify the influence of professional behaviour and perceived development. The second hypothesis is to prove the influence of creativity and perceived development. The third hypothesis is to confirm the literacy and perceived development. The fourth hypothesis is to prove the influence of global understanding and perceived development. The third hypothesis is to confirm the communication and perceived development. All results are shown in table 4.2.

Table 4.1. Result of Multiple Regression Model

\begin{tabular}{|c|c|c|c|c|c|}
\hline $\begin{array}{l}\text { Dependent } \\
\text { Variable }\end{array}$ & $\begin{array}{l}\text { Independent } \\
\text { Variable }\end{array}$ & $\begin{array}{l}\text { Regression } \\
\text { Coefficient } \\
\text { (B) } \\
\end{array}$ & t test & t table & Significance \\
\hline \multirow{6}{*}{$\begin{array}{l}\text { Perceived } \\
\text { Development } \\
\text { (Y) }\end{array}$} & (Constant) & $\bar{~} 1.861$ & & & \\
\hline & $\begin{array}{l}\text { Professional } \\
\text { Behaviour }\left(X_{1}\right)\end{array}$ & 0.268 & 2.894 & 1.662 & 0.000 \\
\hline & Creativity $\left(X_{2}\right)$ & -0.008 & -0.083 & 1.662 & 0.000 \\
\hline & Literacy $\left(X_{3}\right)$ & 0.056 & 0.485 & 1.662 & 0.000 \\
\hline & $\begin{array}{l}\text { Global } \\
\text { Understanding }\left(X_{4}\right)\end{array}$ & 0.134 & 1.506 & 1.662 & 0.000 \\
\hline & Communication $\left(X_{5}\right)$ & 0.206 & 2.024 & 1.662 & 0.000 \\
\hline
\end{tabular}


INOBIS: Jurnal Inovasi Bisnis dan Manajemen Indonesia

Volume 1, Nomor 4, September 2018

Anas Hidayat ; Jaya Addin Linando; Sri Rejeki Ekasasi

The influences value of independent variables toward the dependent variable are:

1. Professional Behaviour (X1) on Perceived Development (Y) is 0.268.

2. Creativity (X2) on Perceived Development (Y) is -0.008 .

3. Literacy (X3) on Perceived Development (Y) is 0.056 .

4. Global Understanding (X4) on Perceived Development (Y) is 0.134.

5. Communication (X5) on Perceived Development (Y) is 0.206 .

\section{Discussion}

The results of this study indicate that professional behaviour had a significant influence on perceived development. It means that IPFE UII professional behaviour trainings impacting on alumnae perceived development. Beside doing the research through questionnaire, the researcher also asked the respondents, what are their suggestions for IPFE UII. The answers were collected and some of the answers refer to the betterment of professional development aspect. The suggestions are that IPFE UII should create tools for student development, such as business incubator, give more practical financial economic class, and also give assistance for the fresh graduates to find the job through IPFE UII alumni who are already working in a certain company. These suggestions are in line with the research result, that the better the professional behaviour value being delivered, the better the professional development of the alumni.

The finding of this research is also in line with what Clark, Mathur \& Schoenfeld (2009) suggested. In their research they found that professional development training need beyond than just workshops, instead it need a comprehensive method of capacity building model of continuous adult learning, which to do so, it requires careful and systemic planning. IPFE UII capacity building programs are already systematically planned under character building curriculum and are applying adult learning method. Probably this is what makes the professional behaviour training from IPFE UII can be well contributed to its alumni perceived development.

The result of this study also shows that creativity influence toward perceived development is negative. The finding need serious attention from IPFE UII, the negative relationship suggest that the current creativity programs from IPFE UII are not effective and in fact is backlashing the development of students. The suggestion discussed in previous chapter that said alumni need business incubator, detail and practical financial economic class can also be considered as the need of creativity training. As the real practices might lead to creativity (Naiman, 2014).

The finding of this research, that creativity influence negatively probably caused by the lack of training quantity that focuses specifically on creativity skill, and that the studens feel the programs are not really develop their capacity. It is being strengthen by the fact that the IPFE UII alumnae are requesting programs that might enhance their creativity skills. IPFE UII can take a lesson from Jacques (2003) research. That the study of creativity can be learned and be reinforced since childhood and also can be developed through training and experience. This is what IPFE UII should do, it is to develop the creativity potential of its student, the creativity potential were already being reinforced since the childhood phase of the students, and IPFE UII should maximize the potential through its programs. Still according to Jacques, the continous process of creativity learning might be applied in the work avenues, meaning that the learning process of creativity might turn into professional development of the students and be usefull for their future professional life. 
INOBIS: Jurnal Inovasi Bisnis dan Manajemen Indonesia

Volume 1, Nomor 4, September 2018

Anas Hidayat ; Jaya Addin Linando; Sri Rejeki Ekasasi

Both of this research result and literature review suggest that creativity is an important factor for the perceived development. This is why IPFE UII should try to deliver the skills in a better manner, because through creativity training, it is hoped that the professional, personal and academic aspects of IPFE UII students might be developed. The results of this study demonstrate that literacy influence perceived development of IPFE UII alumnae is not significant. In IPFE UII, literacy program is mostly being delivered within the bridging program. In the program, students are expected to write, read, and present their ideas, thus they will be used to practice their literature skills.

In the recommendation, some alumnae stated that they are expecting IPFE UII to provide more native lecturers, it is to improve English capability of the student. This recommendation implies that the students feels the need of better literacy training, and interacting with native lecturer is one of the way to achieve the need. The finding and alumnae's recommendation that stated they need more on literacy training is in line with what Nancy (2006) suggest, that literacy training in a broad sense, will enhance students to perform in higher order thinking, which mean that it will led to the development of the students as the participant of literacy programs if the training is well delivered.

The research result shows that global understanding training influence insignificantly on perceived development of IPFE UII alumnae. The influence is a positive influence which means that the better global understanding training, the better the impact on students' development. However, the value of influence is not really significant. It is understandable, since the research was conducted on 2014, and the trend of 2014 and the years before, is that IPFE UII students are not yet eager to go overseas and only focuses on local or national area to develop themselves.

There are several recommendations from the students that implies the need of global understanding training. It is understandable that global understanding becoming one of the most expected training in IPFE UII, as IPFE UII itself is 'international program', meaning that the process of learning inside IPFE UII is aiming for international level outcomes. One of the way to achieve that goal is through student exchance programs. Nowadays IPFE UII is trying to establish more collaboration with foreign university in term of student exchange and dual degree programs, hopefully, these collaborations will open up more chances for the students to gain more global understanding values. The urge to concern on global values is in line with what Forsyth and Maranga (2015) suggest, they believed that the current world is really in a big need for better global leaders to navigate all the complex and ambiguous challenges in the business world. The finding of this research is consistent with the finding from another researches.

The result of this study shows that communication has a positive influence toward perceived development. The better the communication training, the better the result of perceived development felt by the alumnae. It is previously said that the alumnae give recommendation for IPFE UII to provide native lecturers. Beside discuss it under the heading of global understanding, the recommendation can also be discussed under the heading of communication. The existence of native lecturers might allow students to communicate more freely with English language and it will develop their communication skill. It is also relevant with what Combs et al (2015) suggest, that educators are challenged with developing innovative and engaging discipline-specific courses and learning experiences to promote oral communication skills. Knowing the importance of communication skill and that it is also proven that the skill influences on alumnae perceived development, IPFE UII should put more attention toward this training. 
INOBIS: Jurnal Inovasi Bisnis dan Manajemen Indonesia

Volume 1, Nomor 4, September 2018

Anas Hidayat ; Jaya Addin Linando; Sri Rejeki Ekasasi

\section{Conclusion and Recommendation}

From the results of the data analysis and discussion as described in the previous chapter, it can be concluded as follows: Professional behaviour (X1) has a significant influence on the perceived development (Z) of IPFE UII alumnae, it is proved by the result of the $t$ test value. Derived from the first hypothesis, Ho is rejected and Ha is accepted. Thus, the better the professional behaviour will increase the perceived development. Creativity (X2) has a negative influence on the perceived development (Z) of IPFE UII alumnae, it is proved by the result of the t test value. Derived from the second hypothesis, Ho is accepted and Ha is rejected. Literacy (X3) has a positive but not significant influence on the perceived development (Z) of IPFE UII alumnae, it is proved by the result of the $t$ test. Derived from the third hypothesis, Ho is accepted and Ha is rejected. Global understanding (X4) has a positive but not significant influence on the perceived development (Z) of IPFE UII alumnae, it is proved by the result of the $t$ test value. Derived from the fourth hypothesis, Ho is accepted and $\mathrm{Ha}$ is rejected. Communication (X5) has a significant influence on the perceived development (Z) of IPFE UII alumnae, it is proved by the result of the $t$ test value. Derived from the fifth hypothesis, Ho is rejected and $\mathrm{Ha}$ is accepted. Thus, the better the communication will increase the perceived development.

In the recommendation part, it is recommended that, to enhance the professional development, communication and creativity training, it will be good if IPFE create tools such as business incubator, financial economic class, English training class, provide native lecturers, more exchange, dual degree and internship program. Second, regarding to the next phase after the students already graduated, it is better if IPFE provide the links from its alumnae to provide job information for the fresh graduate. So, the graduate of IPFE UII might find the job easier, and it might also form the relationship between alumnae and active students. The last recommendation is regarding to the research, all of the independent variables are positively corelate with the dependent variable. However this research model was way too simple, it is recommended for the future research regarding this issue to make a more advance model, such as but not limited to dig deeper, which variable contribute the most to the dependent variable and which contribute the least, or to add more questions in the questionnaire, or to add more independent variables, etc.

\section{References}

Ali, N., Aslam, H. D., Aslam, M., \& Habib, B. (2013). Importance of Human Resource Management in $21^{\text {st }}$ Century: A Theoretical Perspective. International Journal of Human Resource Studies, 3(3).

Babin, B. J., Carr, J. C., Griffin, M., \& Zikmund, W. G. (2009). Business Research Methods (8th ed.). South-Western: Cengange Learning.

Clark, H. G., Mathur, S. R., \& Schoenfeld, N. A. (2009). Professional Development: A Capacity-Building Model for Juvenile Correctional Education Systems. The Journal of Correctional Education, 60(2).

Combs, E. M., Mayes, L., Stephenson, T. J., \& Webber, K. (2015). Developing Communication Skills of Undergraduate Students Through Innovative Teaching Approaches. NACTA Journal, 2015.

Forsyth, B., \& Maranga, K. (2015). Global Leadership Competencies and Training. Journal of Leadership, Accountability and Ethics, 12(5).

Heneman, R. L. (1999). Emphasizing Analytical Skills in HR Graduate Education: The Ohio State University MLHR Program. Human Resource Management, 38(2). 
INOBIS: Jurnal Inovasi Bisnis dan Manajemen Indonesia

Volume 1, Nomor 4, September 2018

Anas Hidayat ; Jaya Addin Linando; Sri Rejeki Ekasasi

Jacques, L. S. (2003). Cognitive Interplay Between Creative and Organizational Experiences (doctoral dissertation). Alliant International University. Retrieved from ProQuest Dissertations and Theses database. (UMI No. 3101182).

Kleckner, M. J., \& Marshall, C. R. (2015). Critical Communication Skills: Developing Course Competencies to Meet Workforce Needs. The Journal of Research in Business Education, 56(2).

Kroth, M., \& Taylor, B. (2009). Andragogy's Transition Into the Future: Meta-Analysis of Andragogy and Its Search for a Measurable Instrument. Journal of Adult Education, $38(1)$.

Murnane, R., Sawhill, I., \& Snow, C. (2012). Literacy Challenges for the Twenty-First Century: Introducing the Issue. The Future of Children, 22(2).

Naiman, L. (2014). What Is Creativity. Retrieved May 19, 2016, from http://www.creativityatwork.com/2014/02/17/what-is-creativity/.

Nancy, L. (2006). Enhancing Critical Thinking with Aesthetic, Critical and Creative Inquiry. Art Education, 59(5).

Tochon, F. V. (2009). The Key to Global Understanding: World Languages Education-Why Schools Need to Adapt. Review of Educational Research, 79(2). 